\title{
Inyo Redux
}

\section{William Bright \\ University of Colorado}

\section{John McLaughlin \\ Utah State University}

The name of the Inyo Mountains and of Inyo County in California was reported in 1860 to mean 'dwelling place of a great spirit' in a local Indian language, but this etymology was later disputed. It is now confirmed that the name is derived from Panamint ïni-yun 'it's dangerous'.

The California placename Inyo was first applied to a mountain range (east of the Owens Valley, near the Nevada border), and later to Inyo County, in which the range is located. The etymology of the name has been controversial and was the subject of two articles in this journal by the late Madison Beeler $(1972 ; 1978)$. This note proposes a resolution to the controversy in the light of recently gathered data from the native American languages of the area.

As noted by Beeler (1972), a leading etymology for Inyo was proposed by Chalfant $(1922,83)$, citing pioneer records as evidence. According to that account, the Inyo Mountains were so named in 1860 by members of a mining expedition, using a term provided by Chief George, an Indian leader in the Owens Valley area, who said the term meant 'dwelling place of a great spirit'. The term was applied to the county when that unit was established in 1866. This etymology was taken up in the California place name dictionary of Gudde (1962), and was repeated in the 1969 edition. However, no precise linguistic identification or analysis was available; indeed, it was not even clear what tribe or language was the source of the term Inyo. In fact, three distinct though related languages were spoken in the area: Northern Paiute, Mono (also called Monache), and Panamint (also called Tümpisa). All are members of the Numic subgroup of the Uto-Aztecan language family. The Numic languages-which also include Shoshoni, Southern Paiute, and Ute-were spoken natively throughout the Great Basin: in eastern Oregon, southern Idaho, western Wyoming, most of Nevada, all of Utah, western Colorado, and a portion of Arizona.

Names 48.2 (June 2000):147-150

ISSN:0027-7738

(1) 2000 by The American Name Society 


\section{Names 48.2 (June 2000)}

Following a period in which much new field work on California Indian languages had been carried out, especially by students from the University of California at Berkeley, Beeler (1972) pointed out that no linguistic evidence had been adduced to support an American Indian etymology for Inyo, and he proposed an alternative hypothesis: a derivation from Spanish indio 'Indian', a word that was probably known by the first Anglo visitors to Owens Valley. Although Beeler presented no documentary evidence in direct support of this etymology, he later noted (1978), to support the plausibility of his argument, that the name Indio was given by Anglos around 1879 to a town in Riverside County in southern California. The most recent edition of Gudde's dictionary (1998, edited by Bright) records the two competing etymologies, without attempting to evaluate them.

More recent evidence turned up while one of us (Bright) was gathering data on placenames of American Indian origin from all over the U.S., as part of the NAPUS project (Native American Placenames of the United States, being carried out under a contract with the University of Oklahoma Press). The existence of the placenames Inyo Creek and Inyo Mountain in Lemhi County, Idaho, is recorded by Boone (1988, 194), with this comment: "The name reputedly means 'dwelling place of the great spirit' or 'something scary' in the Shoshoni language." It is noteworthy that Boone's phrase "dwelling place of the great spirit" is identical with that used by Chalfant and by Gudde; it seems that Boone may have known of the California name, and perhaps looked it up in Gudde's dictionary. It is even possible that Inyo is a transfer name in Idaho, introduced by Anglo settlers who knew of the term in California (indeed, Boone lists other names transferred from California, such as Oro Fino and Yuba). But Shoshoni is a Numic language, related to the languages of Inyo County in California; so it is possible that the Idaho name was bestowed independently. In fact, forms similar in sound to Inyo occur in several Numic languages of the Great Basin, with meanings relating to the notions 'dangerous, frightening'; these include:

Mono (Western dialect, Madera Co., CA): ini' 'anything dangerous or harmful; white man'; (exclamation) 'watch out!' (Bethel et al. 1993).

Northern Paiute (ID): ini 'scary'; ini-'u 'it's scary' (Liljeblad 1967). 
Panamint (Inyo Co., CA.): innï' 'danger' (Dayley 1989b, 371); with the continuative suffix -yun (Dayley 1989a, 34) this would give innï-yun 'it's dangerous'.

Shoshoni (Duck Valley, ID/NV): ïni 'scary, frightful' (Crum and Dayley 1993, 265); ïni-yu 'it's scary' (McLaughlin, p.c.).

Shoshoni (Gosiute, NV/UT): ïnï, ïnnï 'exclamation indicating surprise or fright' (Miller 1972, 107).

The forms here that most resemble the English name Inyo are those of Panamint and Shoshoni, both languages of the Central Numic division. The native territory of Panamint is close to the Inyo Mountains in California, and it seems most likely that the California name Inyo in fact reflects Panamint ïnï-yun 'it's dangerous'. At the same time, a variety of Shoshoni was spoken in Lemhi County, Idaho, and it is thus quite possible that the Idaho place name Inyo is from Shoshoni ini-yu 'it's scary'; however, it may be the case that the Idaho name was transferred from California.

A basic principle of historical linguistics, including etymology, is that similarity in sound between two forms is not enough to establish a historical relationship; rather, we require the similarity in sound to coincide with significant similarity in meaning or association. Thus E. G. Gudde (1998, xi) criticized the "dictionary etymologists" who derived the name of Putah Creek in California from Spanish puta 'whore', simply because of the similarity in sound, in spite of the absence of any historical association with prostitutes-and in spite of relevant associations with Indian toponymy (in fact, the Lake Miwok name was puta wuwwe 'grassy creek'). In the case of Inyo, we see that the resemblance to Spanish indio, unsupported by other linguistic or historical considerations, is purely fortuitous; but the semantic similarity of Chief George's 'dwelling place of a great spirit' to Panamint or Shoshoni 'it's dangerous, it's scary' gives us a firm basis for determining the origin of at least the California placename. Whether the Inyo in Idaho is a transfer from California or an independent derivation from Shoshoni is still at issue.

\section{Note}

1. The orthographies of the various Numic languages have been normalized for present purposes. Note in particular that the symbol $\ddot{i}$ (a high back unrounded vowel) is used here instead of the symbols $e$ and $y$, which have been used by various authors, for typographic convenience, to write this vowel. 


\section{References}

Beeler, Madison S. 1972. "Inyo." Names 20:56-59. . 1978. "Inyo Once Again.” Names 26:208.

Bethel, Rosalie, Paul Kroskrity and Chris Loether. 1993. A Dictionary of Western Mono. To appear.

Boone, Lalia. 1988. Idaho Place Names: A Geographical Dictionary. Moscow: U of Idaho P.

Chalfant, Willie A. 1922. The Story of Inyo. Chicago: Chalfant. [Rev. ed., Bishop, CA: 1933.]

Crum, Beverly and Jon P. Dayley. 1993. Western Shoshoni Grammar. (Occasional Papers and Monographs in Cultural Anthropology and Linguistics, 1.) Boise, ID: Boise State U.

Dayley, Jon P. 1989a. Tümpisa (Panamint) Shoshone Grammar. (Publications in Linguistics, 115.) Berkeley: U of California P. . 1989b. Tümpisa (Panamint) Shoshone Dictionary. (Publications in Linguistics, 116.) Berkeley: U of California P.

Gudde, Erwin G. 1962. California Place Names. 2nd ed. Berkeley: U of California P. [Third ed., 1969]. . 1998. California Place Names. 4th ed. Ed. William Bright. Berkeley: U of California P.

Liljeblad, Sven. 1967. Northern Paiute Course Materials. Ms.

Miller, Wick R. 1972. Newe Natekwinappeh: Shoshoni Stories and Dictionary. (Anthropological Papers, 94.) Salt Lake City: U of Utah. 